Journal of International Students I 260

Peer-Reviewed Article

ISSN: 2162-3104 Print/ ISSN: 2166-3750 Online

Volume 5, Issue 3 (2015), pp. 260-270

(C) Journal of International Students

http://jistudents.org/

\title{
The Use of the Ombudsman's Services for Alleviating International Students' Difficulties
}

Ourania Katsara, PhD

University of Patras (Greece)

\begin{abstract}
This article offers some suggestions regarding the development of a support strategy by ombudsmen in order to alleviate international students' difficulties when studying in host universities. It is also shown how the Organisational Justice Theory can be used as a framework for understanding the role of ombudsman in higher education settings and how this theory underlines the importance of informational power as a remedy to alleviate the students' difficulties. The main implication drawn from the discussion is that cultural variables may suggest specific care on designing appropriate support strategies where the role of Information Communication Technology (ICT) could be explored. Finally, the article offers some suggestions and a service plan showing how power perceptions of the service provider can impact the students' reaction to the quality of the service.
\end{abstract}

Keywords: ombudsman; information communication technology (ICT); international students; support services; higher education

The origins of the university ombudsman can be found in the United States in Eastern Montana College, where in 1966 the first ombudsman office was established (Stieber, 1991). Twenty years later, ombudsmen offices were established in around 200 colleges and universities in the United States and Canada (Mankin, 1996). In Europe, the European Network for ombudsmen in Higher Education (ENOHE) was formed in 2003. It is an informal network for academic ombudsmen grouping together similar figures such as the Netherlands, Spain, Austria, Switzerland, Germany, United Kingdom, Belgium and others (Alcover, 2009). Wesley (2004) argued that an ombudsman is someone who investigates complaints and acts as a mediator in order to achieve fair settlements between employees, managers, students, professors and sometimes external clients of the organization. The ombudsman's primary roles are consistent with the International Ombudsman Association (IOA) standards of practice. Wesley adds that Ombudsmen should work with individuals or groups in an organization to assist them in determining options to help them resolve conflicts and concerns. They should bring systemic concerns to the attention of the organization for resolution. Confidentiality and maintenance of neutrality with respect to concerns raised is crucial as well as working at an informal level and being independent of formal organizational procedures. 
This article offers some suggestions regarding the development of a support strategy by ombudsmen in order to alleviate international students' difficulties when studying in host universities.

\section{International Student Issues in Higher Education Institutions}

There is evidence in the literature indicating that international students experience administration problems when studying in host universities. A study by Dzansi and Monnapula-Mapesela (2012) has shown that $56.7 \%$ of the international students found their sojourn problematic at South African Central University of Technology. Administration problems appeared to be top in the list of problems reported by international students. Similarly, $87.8 \%$ of the international students' ranked number one the problem item unfriendliness of the immigration officials. This finding implies that it is important to educate the members of staff who represent the face of the hospitality and the friendliness of the entire nation. Obviously, problems of delays in visa extensions, work restrictions and difficulties in becoming South African citizens are issues that policy makers have to pay attention to (Dzansi \& Monnapula-Mapesela, p. 45).

Adrian Taylor et al (2007) found in their survey that both international graduate students and faculty members reported experiencing conflict in their relationships. The main sources of conflict reported by both parties included lack of openness, lack of time and different expectations regarding responsibilities. The findings of the survey undertaken by Adrian Taylor et al (2007) also indicated that both international graduates and supervisors felt that a conflict management service should involve face-to-face interaction with the help of a third person, who is non-judgmental and who has conflict management training. However, students rated the need for additional conflict services higher than supervisors, while the most common suggestion for a third person was the department head. This finding is also consistent with a study undertaken by Zhao et al (2005) who argued that administrators and counselors at universities should help international students by giving them an opportunity to explore the differences and possibilities in intercultural communication.

In a study undertaken by Hambrecht (2006), it was found that international students' cultural norms did prevent them from seeking help while studying in Queensland and that they sought help from friends or relatives. The main implication of the study is that this culturespecific behaviour underlined the importance of reducing embarrassment when seeking support. In a survey by Tilliman (2007) only $10 \%$ of the international students attending a mid-sized technical university in the northeast United States relied on counselling services when experiencing problems. The researcher found that the international students who responded to the survey understood seeking counselling as an acknowledgement of failure.

Taylor (2011) carried out an investigation on Victoria Universities in Australia. This investigation initially focused on the Universities' handling of international students' different type of complaints, but during progress some additional problematic issues arose namely English language admission standards and support services, academic standards and conduct and regulatory arrangements. Some of these problems are reflected in a survey undertaken by Bramford (2008), who found that one of the challenges faced by international students when studying at a UK university concerns the English language ability. Even though there is a minimum language requirement for entry for all international students, some students who have more than met this requirement may not be familiar with technical terminology for a specialised subject area. The survey findings indicated that these students were frustrated by the fact that 
their lecturers have mistaken their lack of technical terminology as having difficulties with language which was not the case.Taylor's report (2011) offers recommendations about good practices in problematic areas, ensuring that Victoria Universities continue to provide quality education to International students. It was indicated that universities should examine the implementation of standards through consultation with academic staff and students, implying that students should 'voice' their opinion.

Research has shown that the Greek case is an example that shows that specific cultural issues have an impact on acculturation and international students' behavior within higher education (Katsara, 2002). The study sought to assess and evaluate the extent of the problems facing Greek students when they come to study at UK universities. Focus groups and questionnaires were used to gather information about the nature and extent of these problems. It was found that some problems persisted throughout the period of study. Many students had arrived without adequate preparation, which exacerbated the situation. The study explored how far communication technology could help prepare students before arrival in the UK. To do this, a novel website was developed specifically for Greeks and backed up by an email response service.

Overall, it was clear that the respondents acknowledged the usefulness of the website in terms of informing them of important issues concerning academic study in UK institutions and that the guidance given, helped them feel more secure in coping with the problems of arriving in a new and unfamiliar environment. An email help line service was also incorporated in the Greek website and students had the opportunity to ask for any clarification of the information provided. Although only a limited service was developed, it did appear to increase confidence, particularly as questions were being answered by a fellow Greek. This finding corroborates Hofstede's cultural dimensions. A central argument is that cultural dimensions may help explain how educational systems reflect social attitudes and values (Hofstede, 1986, 1996,). The Greek culture has strong uncertainty avoidance (UAI: 112) implying that in the Greek educational situation students prefer explicit instruction getting frustrated with the concept of independent learning.

\section{Strategies Used to Alleviate International and Home Students' Problems}

The following sections offer a description of studies, which show that the service of ombudsmen is playing an important role in helping conflicting parties within a university setting improve communication. Enhancing communication refers to how parties communicate information and exchange ideas about their needs, desires, feelings and relationships (Kressel \& Wall 2012). It is implied that the ombudsman's power lies in the fact that he/she should use his influential power to inform all parties involved of the fair procedures used during mediation.

\section{Ombudsman Services}

Barsky (2002) argue that the interdependence among the members of the three university sectors: students, faculty members and support staff member may lead to a permanent interaction between them, with a horizontal character: interactions among members who belong to the same sector and transversal: interactions among members belonging to different sectors and including all possible combinations (Holton\& Phillips, 1995). This hierarchical university structure is often a source of conflict (Barsky, 2002). This is where the university ombudsman can help resolve the conflict by making use of processes of mediation (Alcover, 2009). 
An important distinction related to the types of mediation used by ombudsmen refers to the difference between the processes of formal and informal mediation (Volpe \&Witherspoon, 1992). Volpe and Witherspoon (1992) argue that formal mediation is carried out according to an official procedure previously defined and specified, developed in the statutes of each university and normally approved by the university senate. On the other hand, informal mediation refers to procedures not confined to a standardized procedure and being adapted to the characteristics of the situation, the type of conflict and the parties involved. This type of mediation is carried out in accordance with the evaluation of each ombudsman and improvisation may be a key element in the management of the process (Balachandara, Barrett, Bellman, Fisher \& Susskind, 2005).

Harrisson (2004) undertook a survey on what is considered successful in ombuds' processes. He analyzed forty four cases and carried out 143 interviews to gather data. His results identified that more than $80 \%$ of the participants gave merit to procedural justice where having a voice and control during a process is important in perception of fairness. Nevertheless, specific cases in Harrison's analysis (2004) showed that what constitutes success in ombuds' processes from the ombuds' and disputants' perspective differs. One case referred to a student who thought that he received an unfair exam mark. The student approached the professor twice asking what would have constituted a correct answer on a question. The professor responded orally and the student brought the issue to the ombudsman. Then the ombudsman approached the professor who then provided a long and detailed written response addressing the students' concerns. From the ombudsman's perspective, this was a successful case because the professor was open to the dispute willing to participate in a discussion, while the student's rights were not violated. However, the student thought that the ombudsman was not aggressive enough in his investigation pursuits regarding factual evidence of other students' answers because he was not willing to interfere with the professor's work. Robbins (1993) argues that no ombudsman is successful if the disputant does not understand the outcome. The ombudsman's philosophy of success is one where all parties involved in the dispute respect the rights of all, being open to dialogue about any differences. In this case, these concerns were met for the ombudsman. However, the student was looking more for investigation. This case shows that the student perceived the process as being one about winning or losing and not about constructive dialogue (Harrison, 2004). The above example shows that in terms of ensuring that an equitable and fair resolution is reached in every case a university ombud must explain to all parties that his/her authority is "moral' and that the parties remain relatively in control of their dispute (Field \& Barnes ,2003).

The main implication is that it is necessary to make the objectives of the mediation or the effectiveness criteria clear to the disputants (Alcover, 2009). The mediation process is considered effective when a) it allows for the resolution of the conflict reaching to an agreement and b) it makes a contribution to the improvement of communication between all parties (Van de Vliert, Euwema \& Huismans, 1995). This improvement of communication between all parties is reflected in Organisational Justice Theory, which can be used as a Framework for Understanding the Role of Ombudsman in Higher Education Settings. Poole (2007) argues that organisational justice theory focuses on " how individuals socially construct incidents of justice and injustice in organisational settings" (p.727). Scholars have identified three different aspects of organisational justice: distributive justice, procedural justice and interactional justice. Distributive justice has its roots in Adam's (1965) theory of equity where a social exchange is a two-way transaction in which each side provides something to the other and receives something in return. Procedural justice is defined in terms of fair procedures indicating that just decisions are those that result 
from fair procedures (Leventhal, 1980). Interactional justice as defined by Bies and Moag (1986) focuses on the quality of interpersonal treatment such as respect, sensitivity and explanations for decisions people receive when organisational procedures are implemented.

Perceptions of procedural justice may influence decisions whether to take a formal action in the complaining process (Harrisson, 2007). Harrisson et al (2013) argue that anticipations of procedural justice influence individuals' decisions on how to act when pursuing a grievance. In their study, it was found that students who anticipated higher levels of procedural justice were more likely to intend to use the ombudsman service. Students' responses also revealed that as long as the system remained confidential protecting them from being seen by their professors, they would engage in an ombudsman process.

In this sense, the ombudsman is suggested to be a mediator who exerts power on the individual or group trying to persuade them that the ombudsmen do not report to university emphasizing the confidentiality of the process. Kohli \& Zaltman (1998) argue that power is the ability to effect changes resolving conflicts. Power perceptions therefore of the service provider can impact the recipient's assessment of the quality of the service and the appropriate reaction. The source of power which can be utilized to influence participants in this type of mediation is informational power. Shapira (2009) indicate that under this basis mediators work in different ways to point to the individual's or group's attention of the information which may be relevant for the dialogue between the parties involved.

\section{Use of Technology}

The effectiveness of technology provision as a tool within student services is explored in the literature aiming at supporting a diverse sample of student population with different needs. Pinto and Mansfield (2006) suggested that higher education managers should encourage professors to utilize one of the electronic course management systems where students could post their dissatisfaction online. A survey carried out by Hart and Coates (2011) indicated as well that the item 'send email to the relevant staff members (academic or non-academic' was the most likely response reported by East -Asian students closely followed by 'speak to fellow students' ( p. 62). In similar lines, Hambrecht (2006) found that international students identified issues for improving help and support services. Students reported that implementation of a tertiary student help line or a direct email messaging facility would be useful and would decrease the issue of impersonalization whilst students would remain anonymous. In addition a telephone service would also be a useful instrument.

Thomas et al (2002) argue that some universities lend weight to the attention that active delivery of online support and guidance is an appropriate strategy. They offer as an example the email mentoring scheme set up by Manchester Metropolitan University. This scheme is targeting underrepresented groups, for example disabled students who might not wish or not be able to access other forms of support.

\section{The Ombudsman's Role for International Students}

New possible ways of handling complaints in universities by international students indicates that the manner in which dissatisfied students complain has an impact on educators and universities (Mukherjee, Pinto \& Malhotra, 2009). In addition, a significant shortcoming of the efforts of the U.S. institutions with their retention efforts is emphasised by Ozturgut (2013) who argues that even though international students are supported through a variety of social and cultural activities, there is a strong need for personalized support. 
Literature on customer complaint behaviour indicates that there are four models of complaining behaviour (Day\& Landon, 1977; Singh, 1989) namely voice, negative word of mouth, third party and exit. Voice is linked to direct complaining to the organisation. Negative word of mouth means talking to friends, family, and co-workers. Third party involves complaining to an external entity and exit means no complaining at all where customers stop using the dissatisfying service.

Mukherjee, Pinto and Malhotra (2009) argued that when students manifest their dissatisfaction through 'voice' behaviour, the institution is aware of the problem and has the opportunity to rectify the problem. However, when students are dissatisfied using the negative word of mouth, third party or exit behaviors, the university is unaware of the issue without having any opportunity to improve their support service for future students. It is implied therefore, that institutions should encourage dissatisfied students to engage in 'voice' behavior.

The use of ombudsman services is proposed by Harrison (2007) who indicated that Universities should promote their forums for dispute resolution more actively. They suggested that visibility and knowledge of the ombudsman office could be promoted by including a required statement on all syllabi. This could be appended to the academic integrity statement section. This method could help educate both faculty members and students about options for resolving grievances. This suggestion is also reflected in Cram's work (2010) who argued that Universities should adopt an approach where the use of the web could be used as a new digital strategy, which differentiates the universities by providing avenue of information exchange with the students and stakeholders. This is also underlined in an article by Quilty- Harper (2010) published in Telegraph stating that UK Universities spend millions on redesigns and maintenance of websites which students rate as inadequate. He stated that only $38 \%$ of students taking part in a survey agreed that university websites answer their questions. The need for careful application of ombudsman services in universities is also indicated by Fowlie (2008) who found that respondents of his survey mostly accessed three areas on the ombudsman website: information about who the ombudsman is (about ombudsman), what the ombudsman has done (annual report) and making contact to bring an issue to the ombudsman's attention (complaint, contact forms). This finding has implications on focusing on detail and individual interpretation when redesigning websites.

However, there is little research on meaningful evidence on student retention as a result of specific student services interventions (Thomas et al, 2002). The role of ombudsman services needs to specify its focus within organizations (Newart, 2007). In her paper, the situation of ombudsman services in the U.S. higher education institutions was investigated and it was found that ombudsmen in the U.S. are taking an active role in designing conflict management and dispute resolution systems instead of just filling a function within them. Work undertaken by ombudsmen to design tools to support the assessment of the impact of the services could allow them to be responsible with the capacity to resolve possible dissatisfaction (Thomas et al, 2002). The author of this article is suggesting that ombudsman services could be extended by including the design of appropriate websites with appropriate, relevant and specific information regarding students' needs which come into surface when students make use of complaint services at university. This is also supported by Gill et al (2013) who identified in their research eight ways in which ombudsman services may need to shift their practices in order to respond to the many challenges. These involve ombudsman services becoming more "informal in terms of process; timely in the resolution of complaints; focused on oral/interactive communication with consumers; available to consumers online; visible and accessible to consumers; proactive and 
influential in the policy environment; strategic in influencing service provision; and integrated rather than sectorial" (p. 4).

\section{Suggested Extension of the Ombudsman Service and the Role of ICT}

The role of Information Communication Technology (ICT) could be used by ombudsmen in order to realize the goals of their service. According to Simeon (1999) positioning when examining website strategies of organizations relates to the process of creating a desired image and build position on bases that are relevant and important for clients. Delivering focuses on the way a website provides reliability, speed, security and interactivity including elements such as search engines, e-mail, downloadable software, databases among others. Positioning strategies could be carried out in order to gain valuable insights on how to promote the ombudsman service at higher education settings. This is also indicated by Gill et al (2013) where it was found that participants reported that an increase in consumer awareness of ombudsman schemes is important since consumers need to have a better understanding of the ombudsman institution.

Allen (1999) stressed the importance of websites as information sources in higher education. The research findings revealed that significant proportions of potential students do view the websites of the institutions they are seriously considering applying to. It was also found that potential students also visit websites after they have consulted the prospectus. This suggests that the majority of applicants expected more detail on the website than the prospectus. Allen noted that the interactive nature of the internet is very important since it provides an opportunity to develop a relationship with potential applicants. He suggested that it would be very helpful if institutions provided invitations to potential students to register and receive information on specified areas of interest. Shneiderman (1998) argues that websites are more effective when directed to specific audience niches. Primary audience attributes are gender, age, ethnic origin, economic status, educational background and language.

Katsara (2002) suggested that the following modified steps could be followed in order to ensure that appropriate information material for all cultural backgrounds is gathered. This information could be organised and presented in a website which could be a useful tool that enriches the ombudsman office resources informing students simultaneously about its services. The site could offer sections explaining issues which reflect country-specific issues. These sections could be offered in the relevant language.

Step 1: The ombudsman and associates are suggested to consult closely the literature of international students' experiences in their country and gather valuable data

Step 2: The ombudsman and associates are suggested to hold a series of initial interviews with students from different cultural backgrounds, who had just arrived in their country in order to decide the parameters of the research and to understand the sort of issues which could be helpful to investigate further. The initial information, thus gathered could be used as the basis of a questionnaire which could subsequently be issued to international students who had just arrived to start University. This could prove valuable in identifying and improving our understanding of a range of academic, social, cultural, linguistic and procedural problems which impact on their success.

Step 3: Further focus group interviews are suggested to be held to refine and extend the questionnaire data. After a period of six months a follow up investigation based on a second questionnaire in the same sample of students and further focus group interviews could be undertaken to ascertain whether there had been significant changes in the students' perceptions 
and also to seek information on the sort of solution which might be introduced to mitigate some of the problems raised.

Step 4: As shown in the literature, students would feel more likely to use web-based services to dissolve any problem or worry. Attention therefore should most profitably be focused on the development of web-based strategies. Consequently, a web-based approach could be developed backed up by an online email response service and this could be made available to students six months preceding their arrival to start their studies. The prior delivery stage appears to be crucial. Tsiligiris (2013) also argued that the consideration of student factors prior to delivery allows better planning of the provisions and the necessary actions to re-adjust student expectations and perceptions. The content and the structure of the web pages could be based on scenario design techniques using scenarios constructed by students' opinions and suggestions as a basis for constructing a site and on a detailed analysis of the ombudsman websites of other Universities in the host country.

The aim of the ombudsman websites survey could be to look for good examples of web pages that accorded with international students' worries and complaints. The structure of the site could be based on the stages identified by Lynch and Horton (1999): site definition and planning, information architecture, site design and site construction. They argued that consensus on the overall design approach for the web site needs first to be established. The goal could be to identify potential successful models in other sites and to see the design problem from the user's point of view. Caroll and Rosson (1992) treated design as inquiry. They argued that designers use scenarios to test the usefulness and usability of deign artifacts. During the test process, the designer modifies the design. They suggested that in scenario-based design, the first step involves writing down the scenario in detailed narrative form. Next, the designer makes the claims about the usefulness and usability of certain artifacts in the scenario. In the end, these scenarios and claims constitute the design's description.

Step 5: Feedback from the target students could be gathered, partly during visits to countries to observe and discuss the site as it is accessed by prospective students, and partly using electronic response facilities. An email help line service could be added to the site and users could use it to ask for clarification of the information provided. In addition, an online questionnaire could be added, where the users could assess the usefulness of this tool.

This five-step procedure indicates that students become involved in the process of improving a University service encouraging them to be protagonists. Their level of empowerment is increased since they are engaged in 'voice' behaviour. This is also reflected in a survey undertaken by Harding (2014) where it was found that the facilitative model of mediation was preferred within a university setting. It was found that participants were in favour of a model which focuses on human relationships helping parties to learn to understand the other's point of view. This is also suggested by Alcover (2009) where it is argued that an effective mechanism that could increase harmony in university contexts is the promotion of 'mediation culture' that is values and beliefs that allows the parties to be responsible with capacity to face up and resolve conflicts. This also has some interesting implications on the impact of interactional justice (Bies \& Moag, 1986) where explanations for decisions are given to parties involved.

\section{Closing Thoughts}

The literature in the case of international students studying in host universities indicates that there is a huge responsibility on the part of the host universities to ensure that systems are in place to provide comprehensive support information for these students. It is shown that there is 
an emerging recognition of how important this is but there is clearly a long way to go before there is sufficient understanding of the issues and the measures taken that can be instituted to resolve them. The ombudsman's mission could be to develop such an understanding pointing the way to utilizing the web to deliver his/her service and to ensure that the education experience is rewarding to students and to all who work with them. If ombudsmen manage to act as agents who protect or defend the right for fair treatment, then this mission may turn into reality.

\section{REFERENCES}

Adams, J. S. (1965). Inequity in social exchange. In L. Berkowitz (Eds.), Advances in Experimental social psychology, (pp. 267-299). New York, NY: Academic Press

Adrian-Taylor, S. H., Noels, K. A., Tischler, K. (2007). Conflict between international graduate students and faculty supervisors: Toward effective conflict prevention and management strategies. Journal of Studies in International Education, 11(1), 90-117.

Alcover, C. M. (2009). Ombudsing in higher education: A Contingent model for mediation in university dispute resolution processes. The Spanish J. of Psychology, 1(1), 275-287.

Allen, A. (1999). Higher education institutions, websites as he information sources: Summary and conclusions. Leeds, UK: Heist Publications.

Balachandra, L., Barrett, F., Bellman, H., Fisher, C., \& Susskind, L. (2005). Improvisation and mediation balancing acts. Negotiation Journal, 21, 425-434.

Barsky, A. E. (2002). Structural sources of conflict in a university context. Conflict Resolution Quarterly, 20, 161-176.

Bies, R. J., \& Moag, J. F. (1986). Interactional Justice: Communication criteria of Fairness. Research on Negotiations in Organisations, 1, 43-55.

Bramford, J. K. (2008). Improving international students' experiences of studying in the UK. The Economics Network. Retrieved from: http://www.economicsnetwork.ac.uk/showcase/bamford_international

Caroll, J. M., \& Rosson, M. B. (1992). Getting around the task-artefact cycle: How to make claims and design by scenario. Transactions on Information Systems, 10(2), 181-212.

Cram, J. (2010, October 13). Why are colleges flunking web strategy 101? Fast Company. Retrieved from: http://www.fastcompany.com/1694328/

Day, R. L., \& Landon, L. (1977). Toward a theory or consumer complaining behaviour. In A., G. Woodside, J. N., Sheth, P. D., \& Bennett (Eds.) Foundations of consumer and Industrial Buying Behaviour ( pp. 425-437). New York, NY: Elsevier.

Dzansi, D. Y., \& Monnapula-Mapesela, M. (2012). The nature of International student's adjustment problems in a South African University. Journal for New Generation Sciences, 10(3), 28- 49.

Field, R., \& Barnes, M. (2003). University ombuds: Issues for fair and equitable complaints resolution. Australasian Dispute Resolution Journal, 14(3), 198-210.

Fowlie, F. A. (2008). A blueprint for the evaluation of an ombudsman's office: A case study of the ICANN office of the ombudsman (PhD thesis). La Trobe University, Australia.

Hambrecht, M. F. (2006). Help seeking behaviour of international students: Does culture have an impact? Conference paper National library of Australia Retrieved from: http://trove.nla.gov.au/version/166825705

Harding, C. (2014). Mediation models used in academic settings. Retrieved from: http://ruor.uottawa.ca/handle/10393/31533. 
Gill, C., Williams, J., Brennan, C., \& O'Brien, N. (2013). The future of ombudsman schemes: drivers for change and strategic responses. Queen Margaret University. Retrieved from: www.legalombudsman.org.uk/downloads/documents/publications/QMU-the- futureof-ombudsman-schemes-final-130722.pdf.

Hart, D., \& Coates N. (2011). International student complaint behaviour: Understanding how East-Asian business and management students respond to dissatisfaction during their university experience. International J. of Management Education, 9 (4), 57-65.

Harrison, T. R. (2004). What is success in ombuds processes? Conflict Resolution Quarterly, 21(3), 313-355.

Harrison, T. R. (2007). My professor is so unfair: students' attitudes and experiences of conflict with faculty. Conflict Resolution Quarterly, 24(3), 349-368.

Harrisson, T. R., Hopeck, P., Desrayaud, N., \& Imboden, K. (2013). The relationship between conflict, anticipatory procedural justice and design with intentions to use ombudsman processes. International Journal of Conflict Management, 24 (1), 52-72.

Hofstede, G. (1986). Cultural differences in teaching and learning. International Journal of Intercultural Relations, 10, 301-320.

Hofstede, G. (1996). Differences and danger: Cultural profiles at nations and limits to tolerance. Higher Education in Europe, 21(1), 73-94.

Holton, S. A., \& Phillips. G. (1995). Can't live with them, can't live without them: Faculty and administrators in conflict. New Directions for Higher Education, 23, 43-50.

Katsara O. (2002). Greek students in UK Universities: A support strategy (PhD Thesis). University of Brighton, UK.

Kohli, A. K., \& Zasltman, G. (1988). Measuring multiple buying influences. Industrial Marketing Management, 53(3), 197-204.

Kressel, K., \& Wall, J. (2012). Introduction to the special issue on mediator style. Negotiation Conflict Management Research, 5(4), 334-339.

Leventhal, G. S. (1980). What should be done with equity theory? New Approaches to the study of Fairness in social relationship. In K. J. Gergen, M. S., Greenberg, \& R. H Willis, (Eds.) Social exchange: Advances in theory and research (pp.27-55). New York, NY: Plenum.

Lynch, P. J., \& Horton, S. (1999) Web style guide: Basic design principles for creating websites. London, UK: Yale University Press.

Mankin, L. D. (1996). The role of the ombudsman in higher education. Dispute Resolution Journal. Oct., 46-49.

Mukherjee, A., Pinto, M. B., \& Malhotra, T. (2009). Power perceptions and modes of complaining in higher education. The Service Industry Journal, 29(11), 1615-1633. doi:10.1080/02642060902793383

Newart, M. J. (2007). Ombudsmen in higher education: Similarities, divergences and the rise of alternative dispute resolution, MA dissertation, Cornell University, USA. Retrieved from: dspace.libarary.cornell.edu/marynewhart.

Oztutgut, O. (2013). Best practices in recruiting and retaining international students in the U.S. Current Issues is Education, 16(2), 1-22.

Pinto, M. B., \& Mansfield, P. (2006). The use of computer mediated communication in consumer complaining: A study in higher education. Journal of College Teaching and Learning, 3(1), 83-90. 
Poole, W. L. (2007). Organisational justice as a framework for understanding unionmanagement relations in education, Canadian Journal of Education, 30(3), 725-748.

Quilty-Harper, C. (2010, November 16). Universities spending millions on websites which students rate as inadequate, The Telegraph. Retrieved from: www.telegraph.co.uk/education/universityeducation/8042168/Universities-spendingmillions-on-websites-which-students-rate-as-inadequate

Robbins, L. (1993). Corporate ombudsmen: A shift towards participation in a union environment. J. of Health and Human Resources Administration, 15 (3), 313- 328.

Shapira, O. (2009). Exploring the concept of power in mediation: Mediator's sources of power and influence tactics. Ohio State Journal on Dispute Resolution, 24(3), 1-35.

Sheirderman, B. (1998). Designing the user Interface: Strategies for Effective HumanComputer Interaction. London, UK: Addison Wesley Longman.

Simeon, R. (1999). Evaluating domestic and international web-site strategies. Int. Res. Electron. Network. Appl. Pol., 9(4), 297-308.

Singh, J. (1989). Determinants of consumers' decisions to seek third party redress: An empirical study of dissatisfied patients. Journal of Consumer Affairs, 23, 329-363. doi: 10.1111/j.1745-6606.1989.tb00251.x

Stieber, C. (1991). Reflections: Seventeen years as MSU Ombudsman. MSU Alumni Magazine, Fall, 28-30.

Taylor, J. R. (2011, October 26). Investigation into how universities deal with International students. Retrieved from

globalhighered.files.wordpress.com/2011/investigation_into_how_universities_deal_with _International_students

Thomas, L., Quinn, J., Slack, K., \& Casey, L. (2002). Student services: Effective approaches to retaining students in higher education. Retrieved from http://www.staffs.ac.uk/institutes/access/docs/SSReport.pdf

Tilliman, D. G. (2007). The utilization of counseling by the international student population on US colleges and university campuses. Retrieved from:

http://digitalcommons.brockport.edu/edc_theses.

Van de Vliert, E., Euwema, M. C., \& Huismans. S. E. (1995). Managing conflict with a subordinate or a superior: Effectiveness of conglomerated behavior. Journal of Applied Psychology, 80, 271-281.

Volpe, M. R., \& Witherspoon, R. (1992). Mediation and cultural diversity on college campuses. Mediation Quarterly, 9, 341-351.

Zhao, C. H., Kuh, G. D., \& Carini, R. M. (2005). A comparison of international student and American student engagement in effective educational practices. The Journal of Higher

Education, 76(2), 209-231.

\section{About the Author}

OURANIA KATSARA is English for General and Specific Academic Purposes tutor in University of Patras, Greece. She is teaching specialized English for 11 years. She holds BA in English Language and English and European Literature, MA in Applied Linguistics from University of Essex and PhD from the University of Brighton, UK. Her research interests include intercultural communication, culturally responsive pedagogy, and international education policy and student mobility. E-mail: raniakatsara@hotmail.com 